\title{
Investigation of Middle School Students' Math Self-Efficacy Perceptions and Math Problem Posing Attitudes
}

\author{
Sena Görgün ${ }^{1} \&$ Canses Tican ${ }^{2}$ \\ ${ }^{1}$ Ministry of National Education, Turkey \\ ${ }^{2}$ Mugla Sitki Kocman University, Faculty of Education, Mugla, Turkey \\ Correspondence: Canses Tican, Faculty of Education, Mugla Sitki Kocman University, Mugla, Turkey. E-mail: \\ ctican@hotmail.com
}

Received: July 30, 2020

Accepted: September 20, 2020

Online Published: October 25, 2020

doi:10.5539/ies.v13n11p86

URL: https://doi.org/10.5539/ies.v13n11p86

\begin{abstract}
The main purpose of the current study is to investigate middle school students' math self-efficacy perceptions and math problem posing attitudes. The sample of the study is comprised of 990 fifth, sixth, seventh and eighth grade students attending middle school in the Fethiye district of the city of Muğla. As the data collection tool, the "Math Self-efficacy Perception Scale" and the "Math Problem Posing Attitude Scale" were used. In the analysis of the data collected through the quantitative research method, frequencies, percentages, independent-samples t-test, one-way variance analysis, post-hoc tests (Scheffe and Dunnett's C) and correlation analysis were used. As a result, it was found that the middle school students' math self-efficacy perceptions and math problem posing attitudes are over the medium level. The middle school students' self-efficacy perceptions were found to be varying significantly depending on gender. The middle school students' problem posing attitudes were found to be varying significantly depending on gender. The math self-efficacy perceptions and math problem posing attitudes of the $5^{\text {th }}$ and $6^{\text {th }}$ grade students were found to be significantly higher than those of the $7^{\text {th }}$ and $8^{\text {th }}$ grade students. A medium, positive and significant correlation was found between the middle school students' mean math self-efficacy perception score and their mean math problem posing attitude score.
\end{abstract}

Keywords: self-efficacy perception, math self-efficacy perception, math problem posing attitude, middle school students

\section{Introduction}

As indicated by the saying of Plato "rule yourself; you will find the power to rule the world", one should first start the education process by being aware of his/her weak and strong sides and managing his/her own behaviour. A true education is the process of knowing one's own limits and balancing the line between what they can and cannot do. It is a wrong attitude for an individual to see himself/herself more successful than he/she is just as it is wrong for an individual to see himself/herself more unsuccessful than he/she is in fact. In other words, the individual must be aware of himself/herself and be able to judge himself/herself. For this reason, during the educational and instructional process, it is inevitable for the individual to be confronted with the concept of self-efficacy, which is expressed by Bandura (1997) as the belief in the capacity of the individual to achieve a task at the target level and the extent to which the individual see himself/herself as competent.

One of the goals of today's mathematics education is to train individuals with high problem-posing and solving skills (Milli Eğitim Bakanlığı [MEB], 2018). The perception of self-efficacy of the individual towards mathematics, in other words, the individual's self-confidence towards mathematics may be an important factor in the individual's handling math problems and math-related tasks.

One of the main goals to be achieved in today's mathematics education approach is to create individuals who have developed a sense of curiosity, can solve and pose problems, think critically and believe in the usefulness of doing mathematics and have high mathematical literacy. Posing and solving problems is both an end and a means in mathematics education. Çetinkaya and Soybaş (2018) stated that including problem-posing skills more in the curriculum is important for improving students' reasoning ability and students should be individuals who can do original and independent reasoning, not memorizing question types in patterns.

In the field of mathematics teaching, problem-posing skill has become one of the issues drawing interest in 
addition to problem-solving skill. Thus, math self-efficacy perception can be one of the important factors affecting the problem-posing process. Self-efficacy perception of an individual can directly affect his/her expectations from a process, his/her performance and his/her effort and determination in this process (Zimmerman, 2000). It can be said that mathematics self-efficacy perception affects the problem-posing attitude and the development of mathematical skills. Since individuals' perception of mathematical self-efficacy and their attitudes towards problem-posing may affect individuals' perspectives and approaches towards mathematics, it can be thought that it may also affect an individual's academic and mathematics achievement.

\subsection{Math Self-Efficacy Perception}

Self-efficacy, which emerged with Bandura's "Social Learning Theory" and which is one of the important affective characteristics affecting the learning process of the individual, is defined as "the individual's self-perception in relation to his/her capacity of exhibiting a certain level of performance and organizing the necessary activities to achieve a certain goal and being able to complete it successfully" (Bandura, 1997). Self-efficacy perception can be expressed not as the real competence of the individual in completing a task successfully, but as the individual's feeling competent while completing that task (Öztürk, 2017). Bandura (1997) states that the self-efficacy perception of the individual develops from four different sources: "personal experiences", "indirect experiences", "verbal and social persuasions" and "psychological and emotional states".

Ural, Umay, and Argün (2008) state that an individual's judgments about his/her own abilities in relation to a task and completing this task successfully constitute his/her math self-efficacy perception. In general, math self-efficacy perception can be seen as the belief that the individual can achieve mathematics with his/her own effort. Individuals with high math self-efficacy are aware of their mathematical skills and develop a positive attitude towards problem-posing and approach the problem in a calm and logical manner when faced with complex problems. At the same time, they are expected to have a courageous and faithful attitude when it comes to mathematics, as they have full confidence in mathematics (Gündoğdu, 2013). The mathematics performance of a student who believes that he/she can achieve mathematics can be positively affected by this, which makes contribution to his/her achievement (Şengül \& Gülbağc1, 2013). Math self-efficacy perception can also be expressed as the student's belief that he/she can overcome mathematical problems (İpek, 2019). The student should not only memorize information in patterns, rather should be able to apply the information by making it functional, and should be able to produce new products. It should not be ignored that cognitive skills and affective skills are concepts that support each other. Problems are obstacles encountered by students in mathematics. When faced with a difficult math problem, whether a student can cope with the problem or the way he/she will follow to overcome this difficulty is a result of the student's mathematics self-efficacy perception.

Mathematics self-efficacy perception can affect students' view of mathematics and thus can help students develop positive attitudes towards mathematics. Students with low mathematics self-efficacy perception may think that they will always get low grades from exams, and that they cannot do mathematical activities such as problem-posing and solving, as a result of which they think that they can be criticized by their friends and teachers. Students with high mathematics self-efficacy perception can organize mathematical activities and rely on their own knowledge, capacity and skills in the process of posing or solving a problem and can direct their success.

\subsection{Posing a Math Problem}

According to Silver (1994), "problem-posing is constructing a new problem about a situation or constructing new problems based on the solution of a given problem" (p. 19). According to Stoyanova (1997), problem-posing is defined as the process in which students form their personal interpretations of concrete situations based on their mathematical experiences and form them as meaningfully structured mathematical problems.

Problem solving and posing are skills that are complementary to each other. Problem-posing can be seen as a method of thinking based on some basic principles and concepts of problem solving. According to Silver (1994), problem-posing studies can generally be handled in three different mathematical and cognitive activity forms. These are:

1) Before the solution of a problem: Generating original problems from a stimulating situation presented in the problem.

2) Throughout the solution of a problem: Rearranging a previously solved problem, in other words, reformulating it.

3) After the solution of a problem: Creating new problems by changing the aims or situations of an existing problem. 
Stayanova (2003) examines problem posing in three categories: (1) Free/independent problem posing; (2) Semi-structured problem-posing; (3) Structured problem posing. Christou, Mousoulies, Pittalis, Pitta-Pantazi and Sriraman (2005), on the other hand, classified the problem posing activities into four categories in such a way as to include cognitive process; "organizing quantitative information", "choosing quantitative information", "understanding and organizing quantitative information", "transforming/transferring quantitative information".

Students' being good problem posers positively affects their attitudes towards mathematics. The student in the problem-posing process feels freer as he/she finds the opportunity to actively participate in the process and shape the process according to his/her own will and ability (Soybaş, 2017). Students' being able to pose their own problems and having a say on how to use mathematical expressions develop students' different thinking skills such as asking questions, observing, reasoning and making inferences, and enable students to take an active role in their learning processes.

The concept of attitude is expressed as "the way followed" by the Turkish Language Association [TLA] (2020). Katranc1 and Şengül (2019) defined the attitude towards posing a math problem as "the state of being emotionally and mentally ready to pose a problem or not liking/disliking problem-posing, the belief of being good or bad in problem-posing and the tendency to participate in or avoid problem-posing activities" (p. 4). It is predicted that students who have a negative attitude towards problem posing will not be good problem solvers and their mathematics achievement may be negatively affected by this (Katrancı \& Şengül, 2019). Problem posing attitude can affect the way students approach the problem, their interests and performances. The positive or negative attitudes of the student towards the problem are important factors affecting the problem-posing process. When the literature was reviewed, a sufficient number of studies on attitudes towards posing math problems could not be found. Students with higher mathematical problem-posing skills can be expected to develop a positive attitude towards posing a math problem. In this context, studies on mathematical problem-posing skills as well as mathematical problem-posing attitudes were examined in the literature.

No study investigating math self-efficacy perception and problem posing attitudes together has been found in the literature. The findings obtained from the current study are thought to contribute to the literature and provide valuable data.

\subsection{Purpose of the Study}

The purpose of the current study is to investigate middle school students' math self-efficacy perceptions and math problem posing attitudes. To this end, answers to the following sub-problems were sought.

1) What are the middle school students' math self-efficacy perceptions?

2) Do the middle school students' math self-efficacy perceptions vary significantly depending on the variables of gender and grade level?

3) What are the middle school students' math problem posing attitudes?

4) Do the middle school students' math problem posing attitudes vary significantly depending on the variables of gender and grade level?

5) Is there a significant correlation between the middle school students' math self-efficacy perceptions and math problem posing attitudes?

\section{Method}

\subsection{Research Model}

In the current study, the relational survey model, one of the quantitative research methods, was employed. The relational survey model aims to determine the existence of covariance between two or more variables and/or the degree of the covariance (Karasar, 2018).

\subsection{Population and Sample}

The population of the current study consists of a total of 9217 students $\left(20245^{\text {th }}\right.$ graders, $19606^{\text {th }}$ graders, 2013 $7^{\text {th }}$ graders and $31308^{\text {th }}$ graders) attending the middle schools of the Ministry of National Education in the Fethiye district of the city of Muğla. From these 9127 students, at least 964 students were calculated to be included in the sample according to $95 \%$ probability and $\pm 3 \%$ "acceptable margin of error" (Yazıcıoglu \& Erdoğan, 2007). It was decided to include 990 students in the sample. In this sample, the students from four different grades were included in suitable ratios according to the proportional cluster sampling method. Frequency and percentage distributions of the middle school students across the variables are given in Table 1. 
Table 1. Frequency and percentage distributions of the middle school students across the variables

\begin{tabular}{cccc}
\hline & & $\mathrm{f}$ & $\%$ \\
\hline \multirow{4}{*}{ Gender } & Female & 487 & 49.2 \\
\cline { 2 - 4 } & Male & 503 & 50.8 \\
\cline { 2 - 4 } & Total & 990 & 100.0 \\
\hline \multirow{4}{*}{ Grade Level } & $5^{\text {th }}$ grade & 220 & 22.2 \\
\cline { 2 - 4 } & $6^{\text {th }}$ grade & 210 & 21.2 \\
\cline { 2 - 4 } & $7^{\text {th }}$ grade & 220 & 22.2 \\
\cline { 2 - 4 } & $8^{\text {th }}$ grade & 340 & 34.3 \\
\cline { 2 - 4 } & Total & 990 & 100.0 \\
\hline
\end{tabular}

As can be seen in Table $1,49.2 \%$ of the participating students are females and $50.8 \%$ are males and $22.2 \%$ of them are $5^{\text {th }}$ graders, $21.2 \%$ are $6^{\text {th }}$ graders, $22.2 \%$ are $7^{\text {th }}$ graders and $34.3 \%$ are $8^{\text {th }}$ graders.

\subsection{Data Collection Tools}

\subsubsection{Personal Information Form}

In the personal information form developed by the researcher, there are items to elicit information about the participants' gender and grade level.

\subsubsection{Mathematics Self-Efficacy Scale}

The scale was developed by Umay (2001) in an experimental study called "The Effect of the Elementary School Math Pre-service Teacher Training Program on Math Self-efficacy Perception". The Mathematic Self-efficacy Perception Scale consists of 14 items and 3 sub-dimensions named as "mathematics self-perception", "awareness of behaviours in math subjects" and "transformation of math into life skills". In the study conducted on pre-service teachers, the Cronbach's Alpha reliability coefficient of the scale was calculated to be 0.88 . The median of the validity coefficients of the scale items was found to be 0.64 and this was stated to be accepted as a criterion for the validity of the whole scale. In the current study, the Cronbach's Alpha reliability coefficient of the scale was calculated to be .83 . The Cronbach's Alpha reliability coefficients of the sub-dimensions were found to be as follows: .70 for "mathematics self-perception", .67 for "awareness of behaviours in math subjects" and .73 for "transformation of math into life skills". The lowest score to be taken from the scale is 14 while the highest score is 70 .

\subsubsection{Math Problem Posing Attitude Scale}

The scale was developed by Katrancı and Şengül (2019) for middle school students. The Math Problem Posing Attitude Scale consists of 37 items and three sub-dimensions called "disliking", "seeing unimportant", "self-confidence". The Cronbach's Alpha reliability coefficient was calculated to be 0.93 . The Cronbach's Alpha coefficient was calculated to be for the sub-dimensions as follows: .92 for the sub-dimension of "disliking", .87 for the sub-dimension of "seeing unimportant" and .82 for the sub-dimension of "self-confidence". In the current study, the Cronbach's Alpha reliability coefficient of the scale was found to be .91 for the whole scale and it was found to be .91 for the sub-dimension of "disliking", .84 for the sub-dimension of "seeing unimportant" and .86 for the sub-dimension of "self-confidence". The lowest score to be taken from the scale is 37 while the highest score is 185 .

\subsection{Data Analysis}

The data collected in the current study were analyzed by using SPSS (Statistical Package for the Social Sciences) 22 program package. First, in order to determine which statistical tests would be conducted, it was checked whether the data distributed normally. Within the context of the normality test, Skewness and Kurtosis values were checked. For both of the scales, Sekewness coefficients were found to be between -1.0 and 0.2 and Kurtosis coefficients were found to be between -0.6 and 1.4 for the whole scales and all the sub-dimensions. When Kurtosis and Skewness values are between -1.5 and +1.5 , it is accepted that there is a normal distribution (Tabachnick \& Fidell, 2013). In the analysis of the data, frequencies, percentages, independent samples t-test and one-way variance analysis (ANOVA), Post-Hoc Tests (Scheffe and Dunnett's C) and correlation analysis were used (Taşpınar, 2017).

\section{Findings}

In this section, the findings obtained for the sub-problems of the study are presented. 


\subsection{Findings Related to Middle School Students'Self-Efficacy Perceptions}

The results of the analysis conducted to find an answer to the sub-problem "What are the middle school students' math self-efficacy perceptions?" are presented in Table 2.

Table 2. Middle school students' math self-efficacy perceptions

\begin{tabular}{cccccc}
\hline Dimension & N & Minimum & Maximum & $\overline{\mathrm{X}}$ & SD \\
\hline Math self-perception & 990 & 5.00 & 25.00 & 19.41 & 4.23 \\
Awareness of behaviours in math subjects & 990 & 6.00 & 30.00 & 20.38 & 4.57 \\
Transformation of math into life skills & 990 & 3.00 & 15.00 & 9.91 & 2.81 \\
Math self-efficacy (Total) & 990 & 14.00 & 70.00 & 49.71 & 9.75 \\
\hline
\end{tabular}

As can be seen in Table 2, the Math Self-efficacy Perception Scale is a 5-point Likert scale ranging from "Never" to "Always". The lowest score to be taken from the scale consisted of 14 items is 14 while the highest score is 70 . The median for the scores to be taken from this scale was determined to be 42 . In the current study, the mean score taken by the middle scale students from the scale was found to be 49.71 . Thus, it can be argued that their math self-efficacy perception is over the median ( $\overline{\mathrm{X}}=49.71$; SD:9.75).

\subsection{Findings Related to the Correlations Between the Middle School Students' Math Self-Efficacy Perceptions and Some Variables}

The results of the independent samples t-test conducted to find an answer to the sub-problem "Do the middle school students' math self-efficacy perceptions vary significantly depending on the variable of gender?" are given in Table 3.

Table 3. Results of the independent samples t-test conducted to determine whether the middle school students' math self-efficacy perceptions vary significantly depending on gender

\begin{tabular}{|c|c|c|c|c|c|c|c|c|}
\hline Dimension & Gender & $\mathrm{n}$ & $\overline{\mathrm{X}}$ & Ss & $\mathrm{Sd}$ & $\mathrm{t}$ & $\mathrm{p}$ & Cohen's d \\
\hline \multirow{2}{*}{ Math self-perception } & Female & 487 & 19.69 & 4.23 & \multirow{2}{*}{988} & \multirow{2}{*}{2.081} & \multirow{2}{*}{$.038^{*}$} & \multirow{2}{*}{0.13} \\
\hline & Male & 503 & 19.13 & 4.21 & & & & \\
\hline \multirow{2}{*}{ Awareness of behaviours in math subjects } & Female & 487 & 20.17 & 4.60 & \multirow{2}{*}{988} & \multirow{2}{*}{-1.432} & \multirow{2}{*}{.152} & \multirow{2}{*}{ - } \\
\hline & Male & 503 & 20.59 & 4.53 & & & & \\
\hline \multirow{2}{*}{ Transformation of math into life skills } & Female & 487 & 9.84 & 2.62 & \multirow{2}{*}{979,461} & \multirow{2}{*}{-.717} & \multirow{2}{*}{.473} & \multirow{2}{*}{ - } \\
\hline & Male & 503 & 9.97 & 2.98 & & & & \\
\hline \multirow{2}{*}{ Math self-efficacy (Total) } & Female & 487 & 49.71 & 9.81 & \multirow{2}{*}{988} & \multirow{2}{*}{.024} & \multirow{2}{*}{.981} & \multirow{2}{*}{ - } \\
\hline & Male & 503 & 49.70 & 9.71 & & & & \\
\hline
\end{tabular}

$* p<0.05$.

As can be seen in Table 3, the homogeneity of the variances was examined with levene test. The assumption of the homogeneity of the variances was satisfied for the sub-dimensions of "math self-perception" ( $\mathrm{F}=.018$; $\mathrm{p}=.892>.05)$ and "awareness of behaviours in math subjects" $(\mathrm{F}=.156 ; \mathrm{p}=.693>.05)$ and for the whole scale $(\mathrm{F}=.163 ; \mathrm{p}=.687>.05)$ while this assumption could not be satisfied for the sub-dimension of "transformation of math into life skills" $(\mathrm{F}=8.373 ; \mathrm{p}=.004<.05)$. Therefore, the interpretations were made on the basis of the "equal variance not assumed" $t$ value. According to the results of the independent samples t-test conducted to determine whether the middle school students' math self-efficacy perceptions vary significantly depending on gender, there is a significant difference in the sub-dimension of "math self-perception" $\left[\mathrm{t}_{(988)}=2,081, \mathrm{p}<.05\right]$ in favour of the female students. On the other hand, no gender-based significant difference was found for the sub-dimensions of "awareness of behaviours in math subjects" $\left[\mathrm{t}_{(988)}=-1,432, \mathrm{p}>.05\right]$ and "transformation of math into life skills" $\left[\mathrm{t}_{(979,461)}=-.717, \mathrm{p}>.05\right]$ and for the whole scale $\left[\mathrm{t}_{(988)}=.024, \mathrm{p}>.05\right]$.

The results of the one-way variance analysis conducted to find an answer to the sub-problem "Do the middle school students' math self-efficacy perceptions vary significantly depending on the variable of grade level?" are given in Table 4. 
Table 4. Results of the one-way variance analysis conducted to determine whether the middle school students' math self-efficacy perceptions vary significantly depending on grade level

\begin{tabular}{|c|c|c|c|c|c|c|c|c|c|}
\hline Dimension & Grade & $\mathrm{n}$ & $\bar{X}$ & Ss & sd & $\mathrm{F}$ & $\mathrm{p}$ & $\eta 2$ & Sig. Dif \\
\hline \multirow{5}{*}{ Math self-perception } & 5 & 220 & 20.65 & 3.76 & \multirow{5}{*}{$3-986$} & \multirow{5}{*}{19.005} & \multirow{5}{*}{$.000 *$} & \multirow{5}{*}{.05} & \multirow{5}{*}{$\begin{array}{l}5-7 \\
5-8 \\
6-8 \\
7-8\end{array}$} \\
\hline & 6 & 210 & 20.14 & 3.75 & & & & & \\
\hline & 7 & 220 & 19.37 & 4.11 & & & & & \\
\hline & 8 & 340 & 18.17 & 4.54 & & & & & \\
\hline & Total & 990 & 19.41 & 4.23 & & & & & \\
\hline \multirow{5}{*}{ Awareness of behaviours in math subjects } & 5 & 220 & 22.90 & 4.06 & \multirow{5}{*}{ 3-986 } & \multirow{5}{*}{52.242} & \multirow{5}{*}{$.000^{*}$} & \multirow{5}{*}{.13} & $5-6$ \\
\hline & 6 & 210 & 21.41 & 4.19 & & & & & $5-7$ \\
\hline & 7 & 220 & 19.65 & 4.36 & & & & & $5-8$ \\
\hline & 8 & 340 & 18.58 & 4.33 & & & & & $6-7$ \\
\hline & Total & 990 & 20.38 & 4.57 & & & & & $\begin{array}{l}6-8 \\
7-8\end{array}$ \\
\hline \multirow{5}{*}{ Transformation of math into life skills } & 5 & 220 & 11.14 & 2.55 & \multirow{5}{*}{$3-986$} & \multirow{5}{*}{27.743} & \multirow{5}{*}{$.000^{*}$} & \multirow{5}{*}{.07} & \multirow{5}{*}{$\begin{array}{l}5-6 \\
5-7 \\
5-8 \\
6-8\end{array}$} \\
\hline & 6 & 210 & 10.24 & 2.68 & & & & & \\
\hline & 7 & 220 & 9.66 & 2.72 & & & & & \\
\hline & 8 & 340 & 9.07 & 2.80 & & & & & \\
\hline & Total & 990 & 9.91 & 2.81 & & & & & \\
\hline \multirow{5}{*}{ Math self-efficacy (Total) } & 5 & 220 & 54.70 & 8.38 & \multirow{5}{*}{$3-986$} & \multirow{5}{*}{46.743} & \multirow{5}{*}{$.000^{*}$} & \multirow{5}{*}{.12} & $5-6$ \\
\hline & 6 & 210 & 51.80 & 8.72 & & & & & $5-7$ \\
\hline & 7 & 220 & 48.70 & 9.30 & & & & & $5-8$ \\
\hline & 8 & 340 & 45.83 & 9.73 & & & & & $6-7$ \\
\hline & Total & 990 & 49.71 & 9.75 & & & & & $\begin{array}{l}6-8 \\
7-8\end{array}$ \\
\hline
\end{tabular}

$* \mathrm{p}<.05$.

As can be seen in Table 4, the homogeneity of the measurements was analyzed with levene test. The variances were found to be homogenous in the sub-dimensions of "awareness of behaviours in math subjects" $\left[\mathrm{F}_{(3-986)}=.368, \mathrm{p}=.776>.05\right]$, "transformation of math into life skills" $\left[\mathrm{F}_{(3-986)}=.132, \mathrm{p}=.941>.05\right]$ and in the whole scale $\left[\mathrm{F}_{(3-986)}=1.096, \mathrm{p}=.350>.05\right]$. In the sub-dimension of "math self-efficacy", the variances were found to be not homogenous $\left[\mathrm{F}_{(3-986)}=5.221, \mathrm{p}=.001<.05\right]$. In the cases where the group variances were not equal, Dunnett's $\mathrm{C}$ test was run. As a result of the one-way variance analysis conducted to determine whether the middle school students' math self-efficacy perceptions vary significantly depending on grade level, significant differences were determined in the sub-dimensions of "math self-perception" $\left[\mathrm{F}_{(3-986)}=19.005, \mathrm{p}<.05\right]$, "awareness of behaviours in math subjects" $\left[\mathrm{F}_{(3-986)}=52.242, \mathrm{p}<.05\right]$, "transformation of math into life skills" $\left[\mathrm{F}_{(3-986)}=27.743, \mathrm{p}<.05\right]$ and in the whole scale $\left[\mathrm{F}_{(3-986)}=46.743, \mathrm{p}<.05\right]$. According to the results of Dunnet's $\mathrm{C}$ test conducted to determine between which groups the significant difference is, in the sub-dimension of "math self-perception, a significant difference was found between the $5^{\text {th }}$ graders $\left.\overline{(X}=20.65\right)$ and $7^{\text {th }}$ graders in favour of the $5^{\text {th }}$ graders", between the $5^{\text {th }}$ graders $\left.\overline{(X}=20.65\right)$ and $8^{\text {th }}$ graders $\left.\overline{(X}=18.17\right)$ in favour of the $5^{\text {th }}$ graders, between the $6^{\text {th }}$ graders $\overline{(X}=20.14)$ and $8^{\text {th }}$ graders $\left.\overline{(X}=18.17\right)$ in favour of the $6^{\text {th }}$ graders, between the $7^{\text {th }}$ graders $\overline{(X}=$ 19.37) and $8^{\text {th }}$ graders $\left.\overline{(X}=18.17\right)$ in favour of the $7^{\text {th }}$ graders. According to the results of Scheffe test, in the sub-dimension of "awareness of behaviours in math subjects", there is a significant difference between the $5^{\text {th }}$ graders $\overline{(X}=22.90)$ and $6^{\text {th }}$ graders $\left.\overline{(X}=21.41\right)$ in favour of the $5^{\text {th }}$ graders, between the $5^{\text {th }}$ graders $\overline{(X}=$ $22.90)$ and $7^{\text {th }}$ graders $\left.\overline{(X}=19.65\right)$ in favour of the $5^{\text {th }}$ graders, between the $5^{\text {th }}$ graders $\left.\overline{(X}=22.90\right)$ and $8^{\text {th }}$ graders $\overline{(X}=18.58)$ in favour of the $5^{\text {th }}$ graders, between the $6^{\text {th }}$ graders $\left.\overline{(X}=21.41\right)$ and $7^{\text {th }}$ graders $\overline{(X}=19.65)$ in favour of the $6^{\text {th }}$ graders, between the $6^{\text {th }}$ graders $\left.\overline{(X}=21.41\right)$ and $8^{\text {th }}$ graders $\left.\overline{(X}=18.58\right)$ in favour of the $6^{\text {th }}$ graders, between the $7^{\text {th }}$ graders $\left.\overline{(X}=19.65\right)$ and $8^{\text {th }}$ graders $\left.\overline{(X}=18.58\right)$ in favour of the $8^{\text {th }}$ graders. According to the results of Scheffe test, in the sub-dimension of "transformation of math into life skills", there is a significant difference between the $5^{\text {th }}$ graders $\left.\overline{(X}=11.14\right)$ and the $6^{\text {th }}$ graders $\left.\overline{(X}=10.24\right)$ in favour of the $5^{\text {th }}$ graders, between the $5^{\text {th }}$ graders $\left.\overline{(X}=11.14\right)$ and $7^{\text {th }}$ graders $\left.\overline{(X}=9.66\right)$ in favour of the $5^{\text {th }}$ graders, between the $5^{\text {th }}$ graders $\left.\overline{(X}=11.14\right)$ and $8^{\text {th }}$ graders $\left.\overline{(X}=9.07\right)$ in favour of the $5^{\text {th }}$ graders, between the $6^{\text {th }}$ graders $\overline{(X}=10.24)$ and $8^{\text {th }}$ graders $\left.\overline{(X}=9.07\right)$ in favour of the $6^{\text {th }}$ graders. According to the results of Scheffe test, in the whole scale, there is a significant difference between the $5^{\text {th }}$ graders $\left.\overline{(X}=54.70\right)$ and $6^{\text {th }}$ graders $\overline{(X}=51.80)$ in favour of the $5^{\text {th }}$ graders, between the $5^{\text {th }}$ graders $\left.\overline{(X}=54.70\right)$ and $7^{\text {th }}$ graders $\left.\overline{(X}=48.70\right)$ in 
favour of the $5^{\text {th }}$ graders, between the $5^{\text {th }}$ graders $\left.\overline{(X}=54.70\right)$ and $8^{\text {th }}$ graders $\left.\overline{(X}=45.83\right)$ in favour of the $5^{\text {th }}$ graders, between the $6^{\text {th }}$ graders $\left.\overline{(X}=51.80\right)$ and the $7^{\text {th }}$ graders $\left.\overline{(X}=48.70\right)$ in favour of the $6^{\text {th }}$ graders, between the $6^{\text {th }}$ graders $\left.\overline{(X}=51.80\right)$ and the $8^{\text {th }}$ graders $\left.\overline{(X}=45.83\right)$ in favour of the $6^{\text {th }}$ graders and between the $7^{\text {th }}$ graders $\left.\overline{(X}=48.70\right)$ and the $8^{\text {th }}$ graders $\left.\overline{(X}=45.83\right)$ in favour of the $7^{\text {th }}$ graders. Thus, it was concluded that the math self-efficacy perceptions of the $5^{\text {th }}$ and $6^{\text {th }}$ graders are higher than those of the $7^{\text {th }}$ and $8^{\text {th }}$ graders.

\subsection{Findings Related to the Middle School Students' Math Problem Posing Attitudes}

Table 5. Middle school students' math problem posing attitudes

\begin{tabular}{cccccc}
\hline Dimension & $\mathrm{N}$ & Minimum & Maximum & $\overline{\mathrm{X}}$ & $\mathrm{SD}$ \\
\hline Disliking & 990 & 14.00 & 70.00 & 46.80 & 12.55 \\
Seeing unimportant & 990 & 10.00 & 50.00 & 39.45 & 7.87 \\
Self-confidence & 990 & 13.00 & 65.00 & 48.94 & 9.81 \\
Math problem posing (Total) & 990 & 60.00 & 185.00 & 135.20 & 23.17 \\
\hline
\end{tabular}

The Math Problem Posing Attitude Scale is a five-point Likert scale ranging from "Strongly disagree" to "Strongly agree". The lowest score to be taken from the 37 -item scale is 37 while the highest score is 185 . The median of the scores to be taken from the scale was determined to be 111. In the current study, the mean score taken by the middle school students from the scale is 135.20 . Thus, it can be argued that the middle school students mean math problem posing attitude score $(\overline{\mathrm{X}}=135.20$; SD:23.17) is over the median.

\subsection{Findings Related to the Correlations Between the Middle School Students' Math Problem Posing Attitudes and Some Variables}

The results of the independent samples t-test conducted to find an answer to the sub-problem "Do the middle school students' math problem posing attitudes vary significantly depending on the variable of gender?" are given in Table 6.

Table 6. Results of the independent samples t-test conducted to determine whether the middle school students' math problem posing attitudes vary significantly depending on gender

\begin{tabular}{|c|c|c|c|c|c|c|c|c|}
\hline Dimension & Gender & $\mathrm{n}$ & $\overline{\mathrm{X}}$ & Ss & $\mathrm{Sd}$ & $\mathrm{t}$ & $\mathrm{p}$ & Cohen's d \\
\hline \multirow{2}{*}{ Disliking } & Female & 487 & 47.15 & 12.82 & \multirow{2}{*}{988} & \multirow{2}{*}{.850} & \multirow{2}{*}{.395} & \multirow{2}{*}{-} \\
\hline & Male & 503 & 46.47 & 12.29 & & & & \\
\hline \multirow[b]{2}{*}{ Seeing unimportant } & Female & 487 & 40.79 & 7.49 & \multirow{2}{*}{986.715} & \multirow{2}{*}{5.344} & \multirow{2}{*}{$.000^{*}$} & \multirow{2}{*}{0.34} \\
\hline & Male & 503 & 38.15 & 8.029 & & & & \\
\hline \multirow{2}{*}{ Self-confidence } & Female & 487 & 50.08 & 8.98 & \multirow{2}{*}{974.688} & \multirow{2}{*}{3.624} & \multirow{2}{*}{$.000 *$} & \multirow{2}{*}{0.23} \\
\hline & Male & 503 & 47.84 & 10.43 & & & & \\
\hline \multirow{2}{*}{ Math problem posing (Total) } & Female & 487 & 138.02 & 23.37 & \multirow{2}{*}{988} & \multirow{2}{*}{3.798} & \multirow{2}{*}{$.000^{*}$} & \multirow{2}{*}{0.24} \\
\hline & Male & 503 & 132.46 & 22.65 & & & & \\
\hline
\end{tabular}

${ }^{*} \mathrm{p}<.05$.

As can be seen in Table 6, the homogeneity of the measurements of the variances was examined with levene test. The assumption of the homogeneity of the variances was satisfied in the sub-dimension of "disliking" ( $\mathrm{F}=.665$; $\mathrm{p}=.415>.05)$ and in the whole scale $(\mathrm{F}=.381 ; \mathrm{p}=.537>.05)$. On the other hand, in the sub-dimensions of "seeing unimportant" $(\mathrm{F}=7.211 ; \mathrm{p}=.007<.05)$ and "self-confidence" $(\mathrm{F}=7.267 ; \mathrm{p}=.007<.05)$, this assumption was not satisfied. Therefore, the interpretations were made on the basis of the "equal variance not assumed" $t$ value. According to the results of the independent samples t-test conducted to determine whether the middle school students' math problem posing attitudes vary significantly depending on gender, there is a significant difference in the sub-dimensions of "seeing unimportant" $\left[\mathrm{t}_{(986.715)}=5.344, \mathrm{p}<.05\right]$ and "self-confidence" $\left[\mathrm{t}_{(974.688)}=3.624\right.$, $\mathrm{p}<.05]$ and in the whole scale $[\mathrm{t}(988)=3.798, \mathrm{p}<.05]$ in favour of the female students. No significant difference based on gender was found in the sub-dimension of "disliking" $\left[\mathrm{t}_{(988)}=.850, \mathrm{p}>.05\right]$.

The results of the one-way variance analysis conducted to find an answer to the sub-problem "Do the middle school students' math problem posing attitudes vary significantly depending on the variable of grade level?" are given in Table 7. 
Table 7. Results of the one-way variance analysis conducted to determine whether the middle school students' math problem posing attitudes vary significantly depending on grade level

\begin{tabular}{|c|c|c|c|c|c|c|c|c|c|}
\hline Dimension & Grade & $\mathrm{n}$ & $\bar{X}$ & Ss & $\mathrm{sd}$ & $\mathrm{F}$ & $\mathrm{p}$ & $\eta 2$ & Sig. Dif. \\
\hline \multirow{5}{*}{ Disliking } & 5 & 220 & 51.77 & 11.84 & \multirow{5}{*}{$3-986$} & \multirow{5}{*}{31.730} & \multirow{5}{*}{.000} & \multirow{5}{*}{.08} & $5-7$ \\
\hline & 6 & 210 & 49.61 & 11.31 & & & & & $5-8$ \\
\hline & 7 & 220 & 45.88 & 12.15 & & & & & $6-7$ \\
\hline & 8 & 340 & 42.45 & 12.42 & & & & & $6-8$ \\
\hline & Total & 990 & 46.80 & 12.55 & & & & & $7-8$ \\
\hline \multirow{5}{*}{ Seeing unimportant } & 5 & 220 & 39.96 & 7.99 & \multirow{5}{*}{$3-986$} & \multirow{5}{*}{4.923} & \multirow{5}{*}{.002} & \multirow{5}{*}{.01} & \multirow{5}{*}{$6-8$} \\
\hline & 6 & 210 & 40.54 & 7.51 & & & & & \\
\hline & 7 & 220 & 39.86 & 7.18 & & & & & \\
\hline & 8 & 340 & 38.17 & 8.30 & & & & & \\
\hline & Total & 990 & 39.45 & 7.87 & & & & & \\
\hline \multirow{5}{*}{ Self-confidence } & 5 & 220 & 52.10 & 8.20 & \multirow{5}{*}{$3-986$} & \multirow{5}{*}{16.431} & \multirow{5}{*}{.000} & \multirow{5}{*}{.04} & \multirow{5}{*}{$\begin{array}{l}5-7 \\
5-8 \\
6-8\end{array}$} \\
\hline & 6 & 210 & 50.23 & 8.97 & & & & & \\
\hline & 7 & 220 & 48.13 & 10.35 & & & & & \\
\hline & 8 & 340 & 46.62 & 10.25 & & & & & \\
\hline & Total & 990 & 48.94 & 9.81 & & & & & \\
\hline \multirow{5}{*}{ Math problem posing (Total) } & 5 & 220 & 143.85 & 24.00 & \multirow{5}{*}{$3-986$} & \multirow{5}{*}{29.731} & \multirow{5}{*}{.000} & \multirow{5}{*}{.08} & $5-7$ \\
\hline & 6 & 210 & 140.39 & 21.31 & & & & & $5-8$ \\
\hline & 7 & 220 & 133.88 & 20.98 & & & & & $6-7$ \\
\hline & 8 & 340 & 127.24 & 22.34 & & & & & $6-8$ \\
\hline & Total & 990 & 135.20 & 23.17 & & & & & $7-8$ \\
\hline
\end{tabular}

$* \mathrm{p}<.05$.

As can be seen in Table 7, the homogeneity of the measurements of the variances was examined with levene test. The variances were found to be homogenous in the sub-dimension of "disliking" [ $\left.\mathrm{F}_{(3-986)}=1.270, \mathrm{p}=.284>.05\right]$. However, the variances were found to be not homogenous in the sub-dimensions of "seeing unimportant" $\left[\mathrm{F}_{(3-986)}=3.020, \mathrm{p}=.029<.05\right]$ and "self-confidence" $\left[\mathrm{F}_{(3-986)}=3.339, \mathrm{p}=.019<.05\right]$ and in the whole scale $\left[\mathrm{F}_{(3-986)}=2.892, \mathrm{p}=.034<.05\right]$. In the cases where the group variances were not equal, Dunnett's $\mathrm{C}$ test was run. According to the results of the one-way variance analysis conducted to determine whether the middle school students' math problem posing attitudes vary significantly depending on grade level, there is a significant difference in the sub-dimensions of "disliking" $\left[\mathrm{F}_{(3-986)}=31.730, \mathrm{p}<.05\right]$, "seeing unimportant" $\left[\mathrm{F}_{(3-986)}=4.923\right.$, $\mathrm{p}<.05]$, "self-confidence" $\left[\mathrm{F}_{(3-986)}=16.431, \mathrm{p}<.05\right]$ and in the whole scale $\left[\mathrm{F}_{(3-986)}=29.731, \mathrm{p}<.05\right]$. According to the results of Scheffe test conducted to determine between which groups the difference is, there is a significant difference between the $5^{\text {th }}$ graders $\left.\overline{(X}=51.77\right)$ and the $7^{\text {th }}$ graders $\left.\overline{(X}=45.88\right)$ in favour of the $5^{\text {th }}$ graders, between the $5^{\text {th }}$ graders $\left.\overline{(X}=51.77\right)$ and the $8^{\text {th }}$ graders $\left.\overline{(X}=42.45\right)$ in favour of the $5^{\text {th }}$ graders, between the $6^{\text {th }}$ graders $\left.\overline{(X}=49.61\right)$ and $7^{\text {th }}$ graders $\left.\overline{(X}=45.88\right)$ in favour of the $6^{\text {th }}$ graders, between the $6^{\text {th }}$ graders $\overline{(X}=49.61)$ and $8^{\text {th }}$ graders $\left.\overline{(X}=42.45\right)$ in favour of the $6^{\text {th }}$ graders, between the $7^{\text {th }}$ graders $\left.\overline{(X}=45.88\right)$ and the $8^{\text {th }}$ graders $\left.\overline{(X}=42.45\right)$ in favour of the $7^{\text {th }}$ graders in the sub-dimension of "disliking. According to the results of Dunnett's $C$ test, there is a significant difference between $6^{\text {th }}$ graders $\left.\overline{(X}=40.54\right)$ and $8^{\text {th }}$ graders $\overline{(X}=38.17)$ in favour of the $6^{\text {th }}$ graders in the sub-dimension of "seeing unimportant". According to the results of Dunnett's $C$ test, there is a significant difference between the $5^{\text {th }}$ graders $\left.\overline{(X}=52.10\right)$ and $7^{\text {th }}$ graders $\overline{(X}=48.13)$ in favour of the $5^{\text {th }}$ graders, between the $5^{\text {th }}$ graders $\left.\overline{(X}=52.10\right)$ and the $8^{\text {th }}$ graders $\overline{(X}=46.62)$ in favour of the $5^{\text {th }}$ graders, between the $6^{\text {th }}$ graders $\left.\overline{(X}=50.23\right)$ and the $8^{\text {th }}$ graders $\left.\overline{(X}=46.62\right)$ in favour of the $6^{\text {th }}$ graders in the sub-dimension of "self-confidence". According to the results of Dunnett's $C$ test, there is a significant difference between the $5^{\text {th }}$ graders $\left.\overline{(X}=143.85\right)$ and $7^{\text {th }}$ graders $\left.\overline{(X}=133.88\right)$ in favour of the $5^{\text {th }}$ graders, between the $5^{\text {th }}$ graders $\left.\overline{(X}=143.85\right)$ and the $8^{\text {th }}$ graders $\left.\overline{(X}=127.24\right)$ in favour of the $5^{\text {th }}$ graders, between the $6^{\text {th }}$ graders $\left.\overline{(X}=140.39\right)$ and $7^{\text {th }}$ graders $\left.\overline{(X}=133.88\right)$ in favour of the $6^{\text {th }}$ graders, between the $6^{\text {th }}$ graders $\left.\overline{(X}=140.39\right)$ and the $8^{\text {th }}$ graders $\left.\overline{(X}=127.24\right)$ in favour of the $6^{\text {th }}$ graders, between the $7^{\text {th }}$ graders $\left.\overline{(X}=133.88\right)$ and the $8^{\text {th }}$ graders $\left.\overline{(X}=127.24\right)$ in favour of the $7^{\text {th }}$ graders in the whole scale. Thus, it can be argued that the math problem posing attitudes of the $5^{\text {th }}$ and $6^{\text {th }}$ graders are higher than those of the $7^{\text {th }}$ and $8^{\text {th }}$ graders. 


\subsection{Findings Related to the Correlation Between the Middle School Students' Math Self-Efficacy Perceptions and Math Problem Posing Attitudes}

The results of the correlation test conducted to find an answer to the sub-problem "Is there a significant correlation between the middle school students' math self-efficacy perceptions and math problem posing attitudes" are presented in Table 8 .

Table 8 . Correlations between the middle school students' self-efficacy perceptions and math problem posing attitudes

\begin{tabular}{lllllllll}
\hline Dimension & 1 & 2 & 3 & 4 & 5 & 6 & 7 & 8 \\
\hline 1. Math self-perception & 1 & & & & & & \\
\hline 2. Awareness of behaviours in math subjects & $.55^{* *}$ & 1 & & & & & \\
\hline 3. Transformation of math into life skills & $.45^{* *}$ & $.62^{* *}$ & 1 & & & & \\
\hline $\begin{array}{l}\text { 4. Math self-efficacy } \\
\text { Total }\end{array}$ & $.82^{* *}$ & $.89^{* *}$ & $.77^{* *}$ & 1 & & & \\
\hline 5. Disliking & $.56^{* *}$ & $.54^{* *}$ & $.41^{* *}$ & $.61^{* *}$ & 1 & & \\
\hline 6. Seeing unimportant & $.43^{* *}$ & $.26^{* *}$ & $.24^{* *}$ & $.38^{* *}$ & $.55^{* *}$ & 1 & \\
\hline 7. Self-confidence & $.37^{* *}$ & $.44^{* *}$ & $.51^{* *}$ & $.52^{* *}$ & $.23^{* *}$ & $.34^{* *}$ & 1 \\
\hline $\begin{array}{l}\text { 8. Math problem posing } \\
\text { Total }\end{array}$ & $.61^{* *}$ & $.57^{* *}$ & $.52^{* *}$ & $.68^{* *}$ & $.83^{* *}$ & $.78^{* *}$ & $.66^{* *}$ & 1 \\
\hline
\end{tabular}

$* \mathrm{p}<0.05$.

As can be seen in Table 8, as the assumptions of parametric test were met, Pearson product-moments correlation analysis was used. According to the results obtained from this analysis, there is a medium, positive and significant correlation between the middle school students' mean self-efficacy perception score and mean math problem posing attitude score $(\mathrm{r}=0.68 ; \mathrm{p}<0.05)$.

\section{Discussion}

In the current study, relationships between the middle school students' math self-efficacy perceptions and math problem posing attitudes were investigated. The middle school students' math self-efficacy perceptions were found to be over the median value. In the study conducted by Doruk, Öztürk, and Kaplan (2016), the middle school students' math self-efficacy perceptions were found to be high. In their study, Abal1-Öztürk and Şahin (2015) found that the $5^{\text {th }}$ grade students' math self-efficacy is high. In the studies carried out by Gündoğdu (2013); Şengül and Gülbağc1 (2013), the math self-efficacy of the $7^{\text {th }}$ and $8^{\text {th }}$ graders was found to be high. Usher (2009) also found that the middle school students' math self-efficacy is high. In their study, Adal and Yavuz (2017) concluded that the middle school students' math self-efficacy perceptions are at the medium level and İpek (2019) also concluded that the middle school students' math self-efficacy beliefs are at the medium level. The findings of these studies reported in the literature are similar to the finding of the current study. Thus, it can be argued that in general students see themselves competent in terms of math self-efficacy and this can contribute to students' successful completion of math tasks.

The middle school students' self-efficacy perceptions were found to be varying significantly by gender only in the sub-dimension of "math self-perception" in favour of the female students. İpek (2019) also determined that the female students' math self-efficacy beliefs are higher in the sub-dimension of "indirect experiences". This finding of the study is parallel to the finding of the current study.

In their study conducted on the $5^{\text {th }}$ grade students, Abal1-Öztürk and Şahin (2015) concluded that in the whole scale, math self-efficacy level was found to be higher for the female students. In their studies conducted with the participation of middle school students, Adal and Yavuz (2017); Tella (2011) found that the math self-efficacy of the male students is higher than that of the female students. In their study conducted on high school students, Pajares and Miller (1994) found that math self-efficacy beliefs of the male students are significantly higher. İpek (2019) also found that the male students have higher levels of math self-efficacy beliefs in the sub-dimensions of social persuasions and physiological situations. The findings of these studies reported in the literature do not concur with the finding of the current study.

In the society, there is a general opinion and a cultural bias that female students are not much prone to mathematics (Yıldırım, 2018). According to the results of the research, it can be said that female students feel 
more competent in mathematics and that female students are more patient and determined in the face of the difficulties they encounter in mathematics. This may be due to the different emotional, psychological and social characteristics of female students than male students. The middle school students' math self-efficacy perceptions were found to be not varying significantly depending on gender in the sub-dimensions of "awareness of behaviours in math subjects" and "transformation of math into life skills" and in the whole scale.

The middle school students' math self-efficacy perceptions were found to be varying significantly depending on grade level in the sub-dimensions of "math self-perception", "awareness of behaviours in math subjects" and "transformation of math into life skills" and in the whole scale. Moreover, the math self-efficacy perceptions of the $5^{\text {th }}$ and $6^{\text {th }}$ graders were found to be higher than those of the $7^{\text {th }}$ and $9^{\text {th }}$ graders. Contrary to this finding of the current study, in the study conducted by Gündoğdu (2013) on the $7^{\text {th }}$ and $8^{\text {th }}$ graders, it was found that the math self-efficacy does not vary significantly depending on grade level and Umay (2001) also reported that math self-efficacy perception varies significantly depending on gender but in favour of higher grades.

Parallel to the finding of the current study, Öztürk (2017) found a significant difference in the middle school students' math self-efficacy perceptions in favour of the $5^{\text {th }}$ and $6^{\text {th }}$ graders. In their study conducted on middle school students, Adal and Yavuz (2017) found that the self-efficacy perceptions of the $5^{\text {th }}, 6^{\text {th }}$ and $7^{\text {th }}$ grade students are higher than that of the $8^{\text {th }}$ grade students. In the study conducted with the participation of middle school students, İpek (2019) found that the mean score of the lower grade students is significantly higher than that of the higher grade students. The finding indicating that the self-efficacy perceptions of the $5^{\text {th }}$ and $6^{\text {th }}$ graders are higher than those of the $7^{\text {th }}$ and $8^{\text {th }}$ graders may be because the $7^{\text {th }}$ and $8^{\text {th }}$ graders are in the difficult process of preparation for the high school entrance exam.

The middle school students' math problem posing attitudes were found to be over the median value in the current study. In their study, Katrancı and Şengül (2019) also found that math problem posing attitudes of the middle school students are high. In the study carried out by Ada, Demir, and Öztürk (2020), it was concluded that problem posing decreases prejudices against math problems and thus contributes to the development of positive attitudes in students. In their study, Limin, Van Dooren, and Verschaffel (2013) found that the $5^{\text {th }}$ grade students have positive problem posing beliefs. In the studies conducted by Bayram (2019); Nicolau and Philippou (2007), the middle school students' self-efficacy beliefs about problem posing were found to be high. Çimen and Yildız (2018) concluded that students can pose problems in line with the given bar charts and that their problem posing skills are better than expected. Lin and Leng (2008) conducted a study on gifted middle school students and found that the majority of the students could pose problems successfully.

When the relevant literature is reviewed, it is seen that there are some studies conflicting with the findings of the current study. In the study conducted by Özgen, Aydın, Geçici, and Bayram (2017), it was determined that middle school students were insufficient in problem-posing activities and had difficulty in these activities. Türnüklü, Aydoğdu, and Ergin (2017), in their study with $8^{\text {th }}$ grade students, found that students had difficulty posing problems about triangles and that most of the problems posed were not mathematically sufficient. The fact that students' problem posing attitudes were found to be higher than the average may be due to students' perception that problem posing is useful and beneficial.

When it was investigated whether the middle school students' math problem posing attitudes vary significantly depending on gender, a significant difference was found in favour of the female students in the sub-dimensions of "seeing unimportant" and "self-confidence" and in the whole scale. In their study conducted on middle school students, Katrancı and Şengül (2019) found that problem posing attitudes vary significantly depending on gender in favour the female students. In the study conducted by Turhan-Türkkan (2018), the female students were found to be more successful in problem posing skills. The findings of these studies concur with the finding of the current study.

Akkan, Çakıroğlu, and Güven (2009), in their study examining $6^{\text {th }}$ and $7^{\text {th }}$ grade students' competence to create equations and pose problems, concluded that boys are slightly more competent than girls. This finding is contradictory to the finding of the current study. This difference found in the current study might be because male and female students adopt different critical viewpoints towards problem situations and their creative thinking skills are different from each other. Moreover, the reason for the significant difference in favour of the female students might be because the female students motivated themselves better to pose math problems. No significant gender-based difference was found in the sub-dimension of "disliking".

When it was investigated whether the middle school students' math problem posing attitudes vary significantly depending on grade level, a significant difference was found in the sub-dimensions of "disliking", "seeing unimportant" and "self-confidence" and in the whole scale. Moreover, the math problem posing attitudes of the 
$5^{\text {th }}$ and $6^{\text {th }}$ grade students were found to be higher than those of the $7^{\text {th }}$ and $8^{\text {th }}$ grade students. In their study, Katrancı and Şengül (2019) found that with increasing grade level, middle school students' math problem posing attitudes tend to get worse. In the study conducted by Bayram (2019), it was also found that with increasing grade level, self-efficacy scores related to problem posing tend to decrease. These findings concur with the finding of the current study.

In the study conducted by Bayram (2019), it was determined that the most successful results were obtained by the eighth grade students when the students' problem posing skills were examined. Cai (2003), on the other hand, determined that with increasing grade level, students become more successful in math problem-posing activities. This finding is in contrast to the finding of the current study. In the current study, it was determined that with increasing grade level, the middle school students' math problem posing attitudes got weaker. This might be because of the fact that with increasing grade level, math subjects become more difficult and abstract. Moreover, as the $7^{\text {th }}$ and $8^{\text {th }}$ graders were in the process of preparation of high school acceptance exam, they might have devoted less time to problem posing activities.

A medium, positive and significant correlation was found between the middle school students' self-efficacy perceptions and math problem posing attitudes $(r=0.68)$. Thus, it can be argued that with middle school students' increasing self-efficacy perception, their math problem posing attitudes will also improve. In their study, Ertürk-Geçici and Aydın (2019) concluded that geometry self-efficacy beliefs significantly predict geometry problem posing skills and this finding is in compliance with the finding of the current study. Bayram (2019) on the other hand, found a low and positive correlation between the middle school students' problem posing skills and self-efficacy beliefs related to problem posing. This finding does not concur with the finding of the current study. The student's belief in himself/herself in achieving mathematics will enable him/her to be more patient and constructive in the process of posing a mathematical problem. The student will not give up immediately when faced with negative occurrences. Students with high mathematics self-efficacy perception will also be able to display a positive problem posing attitude.

In light of the findings of the current study, the following suggestions can be made: When the students' math problem posing attitudes were examined in relation to grade level, the math problem posing attitudes of the $5^{\text {th }}$ and $6^{\text {th }}$ graders were found to be higher than those of the $7^{\text {th }}$ and $8^{\text {th }}$ graders. In order to better understand the reasons for this difference, qualitative and quantitative research can be conducted.

Research can be conducted to investigate the reasons behind the lower attitudes of the male students. While there are some studies in the literature focused on the problem posing skill, the number of the studies conducted on middle school students is very small. Studies investigating the relationship between students' problem posing attitudes and different variables can be conducted. Elective courses can be incorporated into curriculums of education faculties to inform pre-service teachers about problem posing and solving strategies.

\section{References}

Abalı-Öztürk, Y., \& Şahin, Ç. (2015). Matematiğe ilişkin akademik başarı, öz yeterlilik ve tutum arasındaki ilişkilerin belirlenmesi. The Journal of Academic Social Science Studies, 31, 343-366. https://doi.org/10.9761/JASSS2621

Ada, K., Demir, F., \& Öztürk, M. (2020). Altıncı sınıf öğrencilerinin problem kurma becerilerinin incelenmesi: Bir durum çalışması. Turkish Journal of Computer and Mathematics Education, 11(1), 210-240.

Adal, A. A., \& Yavuz, İ. (2017). Ortaokul öğrencilerinin matematik öz yeterlik algıları ile matematik kaygı düzeyleri arasındaki ilişki. Uluslararası Alan Eğitimi Dergisi, 3(1), 20-41.

Akkan, Y., Çakıroğlu, Ü., \& Güven, B. (2009). İlköğretim 6. ve 7. sınıf öğrencilerinin denklem oluşturma ve problem kurma yeterlilikleri. Mehmet Akif Ersoy Üniversitesi Ĕ̈itim Fakültesi Dergisi, 9(17), 41-55.

Bandura, A. (1997). Self-efficacy: The exercise of control. New York: Freeman.

Bayram, B. (2019). Ortaokul ögrencilerinin problem kurmaya yönelik beceri ve öz yeterliklerinin incelenmesi (Yayımlanmamış yüksek lisans tezi). Dicle Üniversitesi, Diyarbakır, Türkiye.

Cai, J. (2003). Singaporean students' mathematical thinking in problem solving and problem posing: An exploratory study. International Journal of Mathematical Education in Science and Technology, 34(5), 719-737. https://doi.org/10.1080/00207390310001595401

Christou, C., Mousoulides, N., Pittalis M., Pitta-Pantazi, D., \& Sriraman, B. (2005). An empirical taxonomy of problem posing process. ZDM, 37(3),149-158. https://doi.org/10.1007/s11858-005-0004-6

Çelik, A., \& Özdemir, E. Y. (2011). İlköğretim öğrencilerinin orantısal akıl yürütme becerileri ile problem kurma 
becerileri arasındaki ilişki. Pamukkale Üniversitesi Eğitim Fakültesi Dergisi, 30(30), 1-11.

Çetinkaya, A., \& Soybaş, D. (2018). İlköğretim 8. sınıf öğrencilerinin problem kurma becerilerinin incelenmesi. Kuramsal Eğitimbilim Dergisi, 11(1), 169-200. https://doi.org/10.30831/akukeg.333757

Çimen, E. E., \& Yıldız, Ş. (2018). Altıncı sınıf öğrencilerinin sütun grafiğine uygun problem kurma becerilerinin incelenmesi. Mehmet Akif Ersoy Üniversitesi Eğitim Fakültesi Dergisi, 48, 325-354.

Doruk., M , Öztürk, M., \& Kaplan, A. (2016). Investigation of the self-efficacy perceptions of middle school students towards mathematics: Anxiety and attitude factors. Adlyaman University Journal of Educational Sciences, 6(2), 283-302. https://doi.org/10.17984/adyuebd.306387

Ertürk-Geçici, M., \& Aydın, M. (2019). Sekizinci sınıf öğrencilerinin geometri problemi kurma becerileri ile geometri öz yeterlik inançları arasındaki ilişkinin incelenmesi. Kuramsal Eğitimbilim Dergisi, 12(2), 431-456. https://doi.org/10.30831/akukeg.456427

Gündoğdu, S. (2013). 7. ve 8. sinlf ögrencilerinin sahip olduğu matematiksel güç ile matematik öz yeterliği arasındaki ilişski (Yayımlanmamış yüksek lisans tezi). Eskişehir Osmangazi Üniversitesi, Eskişehir, Türkiye.

İpek, H. (2019). Ortaokul öğrencilerinin matematik kaygılarının matematik öz yeterlik inançlarının ve matematik dersine yönelik öz düzenleme becerilerinin incelenmesi (Yayımlanmamış yüksek lisans tezi). Marmara Üniversitesi, İstanbul, Türkiye.

Karasar, N. (2018). Bilimsel araştırma yöntemi: Kavramlar, ilkeler, teknikler. Ankara: Nobel.

Katranc1, Y., \& Şengül, S. (2019). Ortaokul öğrencilerinin matematik problemi oluşturma, matematik problemi çözme ve matematiğe yönelik tutumları arasındaki ilişkiler. Ĕgitim ve Bilim, 44(197), 1-27.

Limin, C. H. E. N., Van Dooren, W., \& Verschaffel, L. (2013). The relationship between students' problem posing and problem solving abilities and beliefs: A Small-Scale Study with Chinese Elementary School Children. Frontiers of Education in China, 8(1), 147-161. https://doi.org/10.1007/BF03396966

Lin, K. M., \& Leng, L. W. (2008, July). Using problem-posing as an assessment tool. Paper presented at 10th Asia-Pacific Conference on Giftedness, Singapore.

Milli Eğitim Bakanlığı [MEB]. (2018). Matematik dersi ögretim programı (ortaokul 5, 6, 7 ve 8. sinıflar). Ankara: MEB.

Nicolaou, A.A., \& Philippou, G. N. (2007). Efficacy beliefs, problem posing, and mathematics achievements. In D. Pitta-Pantazi, \& G. Phillippou (Eds.), Proceedings of the $v$ congress of the european society for research in mathematics education (pp. 308-317). Larnaca, Department of Education, University of Cyprus.

Özgen, K., Aydın, M., Geçici, M., \& Bayram, B. (2017). Investigation of problem posing skills of eighth grade students in terms of some variables. Turkish Journal of Computer and Mathematics Education, 8(2), 323-351. https://doi.org/10.16949/turkbilmat.322660

Öztürk, B. (2017). Ortaokul ögrencilerinin üst bilişsel farkındalık düzeyi ile matematik öz yeterlik algısının matematik başarısına etkisinin incelenmesi (Yayımlanmamış yüksek lisans tezi). Eskişehir Osmangazi Üniversitesi, Eskişehir, Türkiye.

Pajares, F., \& Miller, M. D. (1994). Role of self-efficacy and self-concept beliefs in mathematical problem solving: A path analysis. Journal of Educational Psychology, 86(2), 193-203. https://doi.org/10.1037/0022-0663.86.2.193

Silver, E. A. (1994). On mathematical problem posing. For the Learning of Mathematics, 14(1), 19-28.

Soybaş, D. (2017). Illköğretim 8. sınıf öğrencilerinin problem kurma becerilerinin incelenmesi (Yayımlanmamış yüksek lisan tezi). Erciyes Üniversitesi, Kayseri, Türkiye.

Stoyanova, E. (1997). Extending and exploring students' problem solving via problem posing: A study of years 8 and 9 students involved in mathematics challenge and enrichment stages of Euler enrichment program for young Australians (Unpublished doctoral dissertation). Edith Cowan University, Perth, Australia.

Stoyanova, E. (2003). Extending students' understanding of mathematics via problem posing. The Australian Mathematics Teacher, 59(2), 32-40.

Şengül, S., \& Gülbağcı, H. (2013). 7. ve 8. sınıf öğrencilerinin sayı hissi ile matematik öz yeterlikleri arasındaki ilişkinin incelenmesi. International Journal of Social Science, 6(4), 1049-1060. https://doi.org/10.9761/JASSS623 
Tabachnick, B. G., \& Fidell, L. S. (2013). Using Multivariate Statistics (6th ed.). Northridge. CA: California State University.

Taşpınar, M. (2017). Sosyal bilimlerde SPSS uygulamalı nicel veri analizi. Ankara: Pegem. https://doi.org/10.14527/9786052410585

Tella, A. (2011). An assessment of mathematics self-efficacy of secondary school students in Osun State, Nigeria. Ife Psychologıa, 19(1), 430-440. https://doi.org/10.4314/ifep.v19i1.64611

Turhan-Türkkan, B. (2018). Ortaokul altıncı sınıf öğrencilerinin kesirlerle işlemlere yönelik problem kurma becerilerinin incelenmesi. İn̈nü Üniversitesi Eğitim Fakültesi Dergisi, 19(3), 374-390. https://doi.org/10.17679/inuefd.358159

Turkish Language Association [TLA]. (2020). Current Turkish dictionary. Retrieved April 25, 2020, from https://sozluk.gov.tr/

Türnüklü, E., Aydoğdu, M. Z., \& Ergin, A. S. (2017). 8. sınıf öğrencilerinin üçgenler konusunda problem kurma çalışmalarının incelenmesi. Bayburt Eğitim Fakültesi Dergisi, 12(24), 467-486.

Umay, A. (2001). İlköğretim matematik öğretmenliği programının matematiğe karşı öz yeterlik algısına etkisi. Journal of Qafqaz University, 8(1), 1-8.

Ural, A., Umay, A., \& Argün, Z. (2008). Öğrenci takımları başarı bölümleri tekniği temelli eğitimin matematikte akademik başarı ve öz yeterliğe etkisi. Hacettepe Üniversitesi Eğitim Fakültesi Dergisi, 35(35), 307-318.

Usher, E. L. (2009). Sources of middle school students' self-efficacy in mathematics: A qualitative investigation. American Educational Research Journal, 46(1), 275-314. https://doi.org/10.3102/0002831208324517

Yazıcıoğlu, Y., \& Erdoğan, S. (2007). SPSS uygulamalı bilimsel araştırma yöntemleri. Ankara: Detay.

Yıldırım, C. (2018). Matematiksel düşünme. İstanbul: Remzi.

Zimmerman, B. J. (2000). Self-efficacy: An essential motive to learn. Contemporary Educational Psychology, 25(1), 82-91. https://doi.org/10.1006/ceps.1999.1016

Note

Note 1 . The current study was produced from Sena Görgün's master's thesis.

\section{Copyrights}

Copyright for this article is retained by the author(s), with first publication rights granted to the journal.

This is an open-access article distributed under the terms and conditions of the Creative Commons Attribution license (http://creativecommons.org/licenses/by/4.0/). 